\title{
Erratum to: Designation of Natural Monuments by the Local Administration: the Example of Viana Do Castelo Municipality and its Engagement with Geoconservation (NW Portugal)
}

Ricardo Jorge Carvalhido ${ }^{1} \cdot$ José B. Brilha $^{1} \cdot$ Diamantino I. Pereira $^{1}$

Published online: 29 June 2016

(C) The European Association for Conservation of the Geological Heritage 2016

Erratum to: Geoheritage

DOI 10.1007/s12371-016-0191-2

The original version of this article unfortunately contained a mistake. The four occurrences of the word "geopark" were incorrect and should be replaced with "geological park".

The online version of the original article can be found at http:// dx.doi.org/10.1007/s12371-016-0183-2.

Ricardo Jorge Carvalhido carvalhido@dct.uminho.pt

Institute of Earth Sciences, Pole of University of Minho,

Braga, Portugal 